4. Gobato A.O., Vasques A.C.J., Zambon M.P., Barros Filho A.A., Hessel G. Metabolic syndrome and insulin resistance in obese adolescents. Rev. Paul. Pediatr. 2014. Vol. 32 (1). P. 55-62.

5. Guo S.-X., Yan Y.-Z., Mu L.-T., Niu Q., He J., Liu J.-M., et al. Association of serum free fatty acids with hypertension and insulin resistance among rural uyghur adults in Far Western China. Int. J. Environ. Res. Public Health. 2015. Vol. 12 (6). P. 6582-6590.

6. Martos-Moreno G.A., Gil-Campos M., Bueno G., Bahillo P., Bernal S., Feliu A., et al. Obesity associated metabolic impairment is evident at early ages: spanish collaborative study. Nutr. Hosp. 2014. Vol. 30 (4). P. 787-793.

DOI https://doi.org/10.30525/978-9934-588-81-5-2.8

\title{
МОРФОЛОГІЧНІ ЗМІНИ СТІНКИ СЕЧОВОГО МІХУРА ПІД ДІЄЮ ДИМЕТИЛСУЛЬФОКСИНУ
}

\author{
Гончарук В. В. \\ аспірант кафедри нормальної анатомії
}

Вінницький національний медичний університет імені М. І. Пирогова

Костюк О. Г.

доктор медичних наук, професор,

завідувач кафедри променевої діагностики, променевої терапії і онкологї

Вінницький національний медичний університет імені М. І. Пирогова м. Вінниия, Украӥна

Рак сечового міхура (РСМ) відносять до найбільш частих злоякісних новоутворень, займаючи шосте місце серед чоловіків та 17 місце серед жінок в загальній структурі онкологічної захворюваності (WHO, Bladder cancer statistics, 2018). В Україні у 2018 році, за даними Національного канцерреєстру, рак сечового міхура в загальній структурі онкологічної захворюваності займає дев'яте місце. Рецидив ПРСМ це важлива не вирішена пороблена сьогодення [5]. Рецидиви ПРСМ призводять до зменшення ступеню диференціації пухлин, що в свою чергу призводить до розвитку IPCM [4]

У вітчизняній та іноземної наукової літератури, знайдено незначну кількість інформації про морфологічні зміни в слизовій оболонці стінки сечового міхура при застосуванні внутрішньоміхурової хіміотера36 
пії в якості лікування та протирецидивного внутрішньоміхурового лікування ПРСМ $[1,2]$. Не вивчені повнота та строки відновлення структури стінки сечового міхура після внутрішньоміхурового введення хіміопрепаратів затверджених протоколами МО3 України 3 приводу лікування та профілактики рецидивів поверхневого раку сечового міхура [3]. Не вирішеним залишається питання щодо зменшення концентрації хімвіопрепаратів при лікуванні РСМ при використанні такого загальновідомого транспорстного антисептика як диметилсільсоксин. Морфологічні засади такого поєднаного використання і зовсім відсутні.

Саме тому метою нашого дослідження було встановити закономірності морфологічних змін стінки сечового міхура щурів у нормі та при застосуванні внутрішньоміхурової хіміотерапії в експерименті. Досліди були проведені на 82 білих безпородних щурах, обох статей, віком 5-6 місяців, масою 200-270 г, які поділені на п’ять груп. Безпосередньо вплив різних концентрацій диметилсульфоксина та його транспортної дії на стінку сечового міхура вивчали у на щурах трьох груп. Для адекватного порівняння отриманих в експерименті даних білу створена перша група - контрольна, яким препарати не вводилися і яка поділена на п’ять підгруп в залежності від строків виведення із експерименту (виводяться до експерименту - для визначення особливостей морфологічної структури даної групи тварин, через дві години, три, сім та двадцять одну добу), оскільки у зв'язку із ростом тварини морфологія стінки сечового міхура в нормі могла змінитися. Друга група - для виявлення концентрації розчина диметилсульфоксина, яка б володіла найменшими негативними наслідками впливу на слизову оболонку сечового міхура. Таким щурам внутрішньоміхурово вводили розчин диметилсульфоксина трьох різних концентраціях : 10\%, 30\%, 50\% поділена на чотири підгрупи в залежності від виведення із експерименту (евтаназію проводили через дві години, три, сім та двадцять одну добу). Третя група - для виявлення транспортної дії диметилсульфоксина. Вона була поділена на дві підгрупи: перша - тваринам внутрішньоміхурово вводили розчин барвника за Романовським-Гімзою; друга -, яким внутрішньоміхурово вводили розчин барвника за Романовським-Гімзою в розчині диметилсульфоксина певної концентрації. Тварин виводили із експерименту через дві години.

Дослідження було проведене на базі проблемної науково-дослідної лабораторії функціональної морфології та генетики розвитку НДЦ ВНМУ ім. М. І. Пирогова, що сертифікована ДФЦ МОЗ України (посвідчення № 003/10 від 11.01.2010 року) Всі маніпуляції з твари- 
нами та їх утримання проводили відповідно до «Загальних етичних принципів експериментів на тваринах», ухвалених Першим національним конгресом з біоетики (Київ, 2001), також керувалися рекомендаціями «Европейської конвенції про захист хребетних тварин, які використовуються для експериментальних та інших наукових цілей» (Страсбург, 1985) і положеннями «Правил доклінічної оцінки безпеки фармакологічних засобів (GLP), у повній мірі дотримувалися правил гуманного відношення до експериментальних тварин, що підтверджено комітетом з біоетики ВНМУ ім. М. І. Пирогова (протокол № 1 від 14.01.2010 року;

Загальну анестезію проводили кетаміном з розрахунку 0.2 мл на 100 грам маси тіла -0.6 мл. Після видалення волосяного покриву передньої черевної стінки та асептичної обробки операційного поля за Пироговим, виконували пошаровий доступ до сечового міхура (CM) 3 наступним його виділенням та масажуванням до повного спустошення. Через анатомічні особливості будови уретри щурів, ретроградна катетеризація СМ була не можлива і було вирішено вводити препарат безпосередньо в порожнину СМ за допомогою інсулінового шприца. У порожнину СМ вводили $10 \%$ розчин диметилсульфоксину в об'ємі 0.3-0,4 мл. на 2 години. Після введення препарату щура виводили із експерименту шляхом дислокації шийних хребців під кетаміновим наркозом у строки відповідно до плану експерименту. Після евтаназії видаляли сечовий міхур із наступним морфологічним дослідженням та маркуванням біоптатів.

Для гістологічного дослідження вирізали 5 шматочків стінки сечового міхура - із задньої стінки, правої стінки, лівої стінки, верхівки, шийки, фіксували у нейтральному формаліні $10 \%$ протягом 48 годин, промивали, зневоднювали шляхом проведення через батарею спиртів зростаючої концентрації, проводили через хлороформ та готували парафінові блоки. Зрізи стінок сечового міхура товщиною 5-7 мкм готували на ротаційному мікротомі (серії НM 340Е), розміщували на склі. Для вивчення морфоцитоархітектоніки стінки сечового міхура забарвлювали зрізи гематоксилін-еозином та за Ван-Гізон (для встановлення змін питомої ваги сполучної тканини). Гістологічне дослідження стінки сечового міхура здійснювали на мікроскопі Laborlux S (Leitz) при збільшеннях у 40, 100, 200 і 400 разів.

Встановлено, що через дві години після використання розчину диметилсульфоксину, відмічалися морфологічні зміни у внутрішніх органах. Найбільш вираженими вони були у сечовому міхурі у групах, де використовували 30\%та 50\% концентрацію препарату, що відобра- 
жалося у порушеннях кровообігу та дистрофії епітелію слизової оболонки. В усіх випадках (при використанні усіх концентрацій мало місце розширене повнокров'я судин підслизової основи, а у випадках $30 \%$ та 50\% концентрації розчину - воно супроводжувалося діапедезними крововиливами. При використанні розчину вищеозначених концентрацій також мали місце зміни епітеліоцитів слизової оболонки у вигляді їх балоновидної дистрофії у поверхневому та проміжних шаpax. Ми звернули увагу на те, що подекуди змінилася цитоархітектоніка слизової оболонки сечового міхура - кількість клітин, у середньому, стала більшою (до семи у шарі).

Морфологічні зміни у сечовому міхурі через дві доби після використання диметилсульфоксину біли відмічені тільки у випадках використання $30 \%$ та $50 \%$ його розчину і проявлялися підвищеною проникністю та повнокров'ям гемокапілярів, незначною лейкоцитарною інфільтрацією. Мали місце дрібновогнищеві діапедезні крововиливи на фоні нерівномірного повнокров'я гемокапілярів у підслизовій основі,, причому питома вага посткапілярів та венул стала більшою у 2,32 рази $(\mathrm{p}<0,05)$, а у 4 випадках ми спостерігали розсіяну інфильтрацію еозинофільними лейкоцитами.

На сьому добу експерименту гістоархитектоніка стінки сечового міхура не була порушена у всіх випадках використання розчину диметилсульфоксину. Епітеліоцити слизової оболонки в значній мірі мали просвітлену цитоплазму, питома вага венулярного ланцюга гемомікроциркуляторного русла була незначно збільшена відносно контролю, діапедезних крововиливів не було. Ми помітили незначну тенденцію до збільшення питомої ваги сполучної тканини (на 0,23 відносно контролю).

На 21 добу експерименту ми не виявили будь-яких морфологічних змін зі сторони стінки сечового міхура експериментальних тварин, незалежно від концентрації використаного розчину. Всі морфологічні зміни прямо залежали від величини концентрації розчину диметилсульфоксину, але мали меншу вираженість, у порівнянні з попередніми строками експерименту. На гістологічному рівні було встановлено, що найменш шкідлива концентрація використання диметилсульфоксину складає $10 \%$.

Для виявлення транспортної дії диметилсульфоксину концентрації $10 \%$ ми використали дві підгрупи експериментальних тварин: перша тваринам внутрішньоміхурово вводили розчин барвника за Романовським-Гімзою; друга група тварин, яким внутрішньоміхурово вводили розчин барвника за Романовським-Гімзою в розчині диметилсульфок- 
сину певної концентрації, що дало нам ще 3 підгрупи - на 10\%, 30\% та 50\%. Тварин виводили із експерименту через дві години. При використанні «чистого» розчину барвника за Романовським-Гімзою через 2 години ми знайшли незначне забарвлення базальної підслизової пластинки. При використанні суміші барвника та диметилсульфоксину через 2 години ми виявили забарвлення підслизового шару пухкої сполучної тканини i, подекуди - забарвлення сполучнотканинних елементів м'язового шару стінки сечового міхура при використанні будь-якої концентрації.

Таким чином, експериментально та морфологічно доведена висока транспортна здатність розчину диметилсульфоксиду в усіх концентраціях. Найменш токсичною виявилася концентрація 10\%, що дозволило нам використати іiі у подальших експериментах при доборі дози введення хіміопрепаратів.

\section{Література:}

1. Вітрук Ю.В. Стаховський Е.О. Войленко О.А. Стаховський О.Е. Сучасні системи оцінки пухлинного ураження нирки (огляд літератури). Клінічна онкологія. № 3 (11). 2013. С. 84-88

2. Стаховський О.Е. Федоренко 3.П. Вітрук Ю.В. Литвиненко Р.А. Скринінг раку передміхурової залози. Клінічна онкологія. № 1 (21). 2016. C. $44-48$

3. Старченко I.I., Бабенко B.I., Прилуцький О.К., Сидоренко М.I., Старченко О.В. Деякі епідеміологічні та клініко-морфологічні особливості раку сечового міхура. Вісник проблем біології $і$ медицини. Вип. 1. Т. 2. 2018. С. 33-35

4. Боженко В.К., Кулинич Т.М., Мельникова Н.В., Нестеров П.В. Лабораторная диагностика рака мочевого пузыря. - ФГУ «РНЦРР Росмедтехнологий», Г. Москва. [Електронний ресурс]: http:www. vestnik.rncrr.ru/vestnik/v8/papers/bozh1_v8.htm (дата звернення: 19.03.2018).

5. Alex Vassilev and Melvin L. DePamphilis. Links between DNA replication, stem cells and cancer. Genes. 2017, 8(2), 45; doi:10.3390. 